\title{
Current Surgical Management of Erectile Dysfunction
}

\author{
Erektil Disfonksiyonun Mevcut Cerrahi Tedavisi
}

\author{
Memduh Aydın, Aydın İsmet Hazar \\ Department of Urology, Taksim Research and Training Hospital, İstanbul, Turkey
}

\begin{abstract}

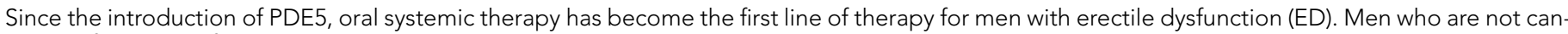

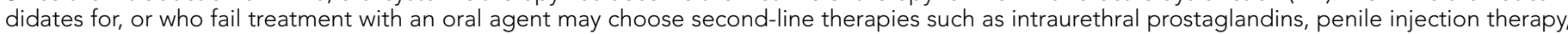

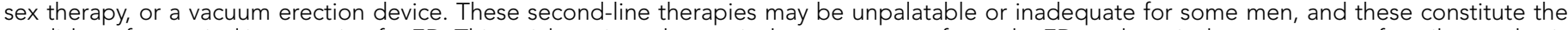

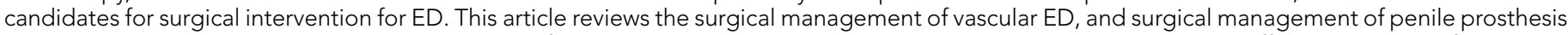

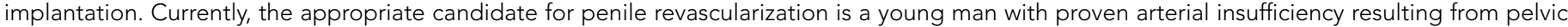
trauma. (JAREM 2011; 1: 61-4)
\end{abstract}

Key Words: PDE5 Ihibitör, erectile dysfunction, penile revascularization, penile prostheses

\section{ÖZET}

Erektil disfonksiyonlu erkeklerin tedavisine oral PDE5 ihibitörlerin devreye girmesiyle ilk tedavi seçeneği olarak kabul gördü. Oral ajanların tedavisinin yetersiz kaldığı erkeklerde sekonder tedavi yöntemlerine geçilir. İntrauretral prostaglandinler, penil enjeksiyon tedavisi, seks terapisi, ya da vakum ereksiyon cihazları gibi tedavi yöntemleri bu grubu oluşturur. Bununla birlikte bu tedavi yöntemleri yetersiz kalabilmekte ya da bazı hastalar tarafından hoş karşılanmayabilmektedir. Bu tedavi seçeneklerinden sonraki hastalar cerrahi olarak tedavi edilecek hasta adayları oluşturur. Bu derlemede, genellikle pelvik travmalara bağlı penil arteryel yetersizlik gelişen erektil disfonksiyon hastalarına yapılan penil revaskülarizasyon ve penil implant ameliyatları anlatılmıştır. (JAREM 2011; 1: 61-4)

Anahtar Sözcükler: PDE5 ihibitör, erektil disfonksiyon, penil revaskülarizasyon, penil protezler

Three sentinel events define the history of the treatment of erectile dysfunction (ED). These are introduction of the inflatable penile prosthesis in 1973, intracavernous injection therapy in 1982, and effective systemic therapy with sidenafil citrate in $1998(1,2)$. Today, the treatment of ED can be likened to the treatment of osteoarthritis, another common disorder that also becomes more prevalent with age. In both, a progresive treatment model may be employed. Most men with ED are initially offered systemic therapy with a phosphodiestrase type 5 (PDE-5) inhibitor. When that fails and the man wishes to continue treatment, second-and third line therapies should be discussed. When these fail or are rejected, penile prosthesis implantation is usually appropriate.

\section{Penile implants}

Penile implants were introduced into the marketplace over 30 years ago with the marketing of three piece inflatable and semi rigid rod almost simultaneously (Table 1, 2) $(3,4)$. A patient would be considered a good candidate for a penile prosthesis if he had failed medical therapy or if medical therapy was contraindicated. Patients are usually advised to consider a vacuum device before a penile implant. There are three classes of penile implants, hydraulic, semirigid, and soft silicon (Table 1, 2, Figure 1, 2). This early inflatable penile prosthesis was associated with mechanical failure rates ranging from 21 to $45 \%$ within a few years after implantation $(5,6)$. The two piece inflatable penil prosthesis (Table 1, Figure 1) consists of two cylinders connected to a small scrotal pump. Squeezing this pump transfers a small volume of fluid from the rear tip reservoirs of the cylinders into a nondistensible central chamber, producing rigidity comparable to that of a mal- leable device. When the device is deflated, the central chamber partially collapses, providing better flaccidity than a malleable implant. The two-piece prothesis has as its primary advantage ease of implantation because there is no third piece (abdominal fluid reservior). A disadvantage compared with malleable devices is the increased risk of mechanical failure. Three-piece protheses (Table 1, Figure 1) have paired corporeal cylinders, a scrotal pump, and an abdominal fluid reservior. All three-piece devices provide penile girth expansion and rigidity similar to that of a normal erection (7). Malleable prostheses are semirigid devices with a central core that allows the penis to be bent down for dressing and bent upward for coitus. However, for most men, this malleable core does not maintain these positions very well. Malleable devices have the advantage of very low mechanical failure rates and ease of use. Disadvantages include constant penile rigidity and increased risk of erosion (8).

Pre-operative preparation: It is recommended that the patients bathe the genital area with a strong soap for a few days prior to surgery. Shaving of the genital area is performed in the operating room to minimize the chance of nicks in the skin being colonized by bacteria with prior shaving. The urine culture should be negative if possible. Antibiotics are usually started prophylactically one hour prior to the procedure. The antibiotics are usually continued for 48 hours postoperatively. Some surgeons prefer to maintain antibiotics for a week after surgery. A catheter is sometimes used to identify the corpus spongiosum during the procedure and may be removed at the conclusion of the operation or continued for up to 24 hours in the post operative period. 
Table 1. Inflatable penile prostheses

\begin{tabular}{|l|c|c|}
\hline Name & Type & Company \\
\hline AMS Ambicor & Two piece & American Medical system \\
\hline Excel & Two piece & Coloplast Corporation \\
\hline AMS 700MS series & Three piece & American Medical system \\
\hline Titan Inflatable penile prosthesis & Three piece & Coloplast Corporation
\end{tabular}

\section{Table 2. Noninflatable penile protheses}

\begin{tabular}{|c|c|c|c|}
\hline Name & Type & Company & Country \\
\hline HR Penile prostheses & Malleable & & Brazil \\
\hline Silimed Malleable & Malleable & www.silimed.com br & Brazil \\
\hline Jonas (ESKA) & Malleable & www.Eska-medica.com & Germany \\
\hline Apollo Implant & Tissue expander & Gigant Medical & Italy \\
\hline Genesis Mallable & Malleable & Coloplast & USA \\
\hline AMS Malleable 650/600M & Malleable & American Medical Systems & USA \\
\hline AMS Dura II & Positionable & American Medical Systems & USA \\
\hline
\end{tabular}

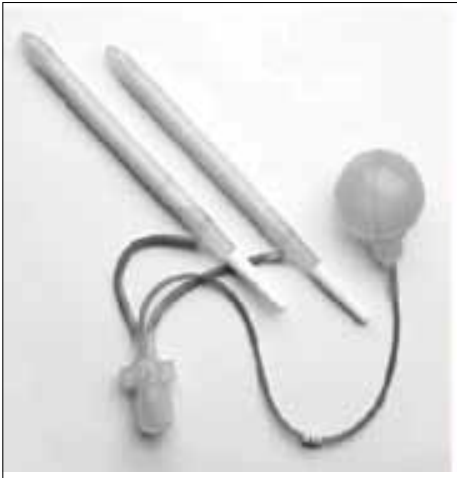

AMS (American medical systems) 700 series

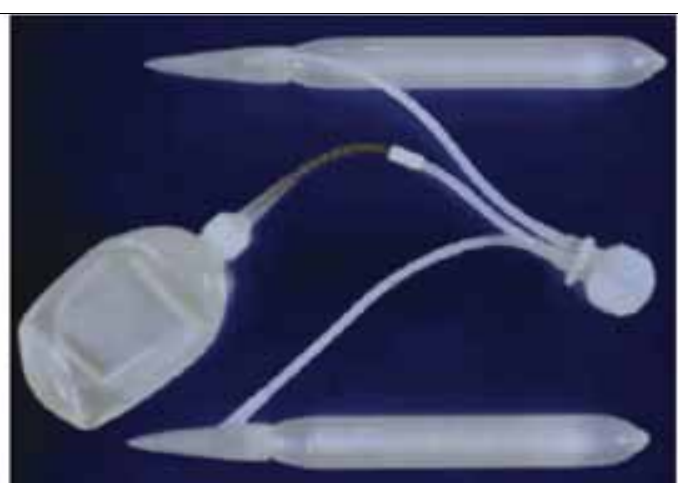

Mentor Alpha I-Three-piece inflatable penile implant

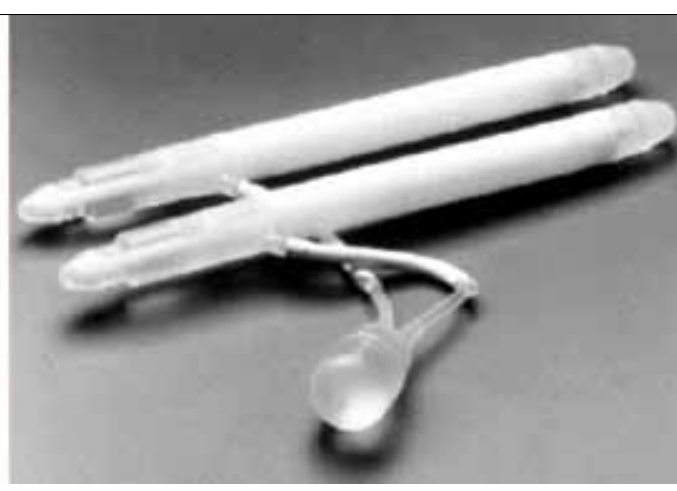

Ambicor 2-piece penile implant

Figure 1. Inflatable penile prostheses

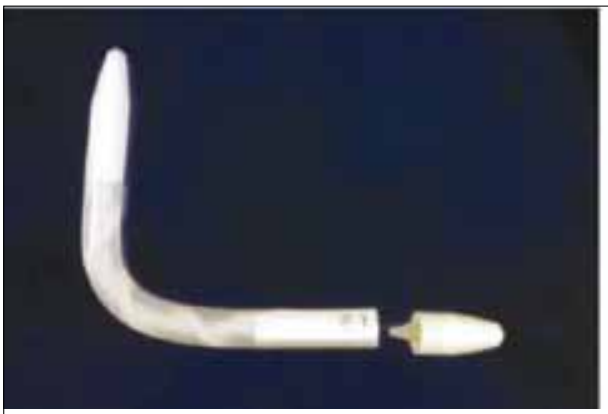

Accuform semirigid rod penile implant

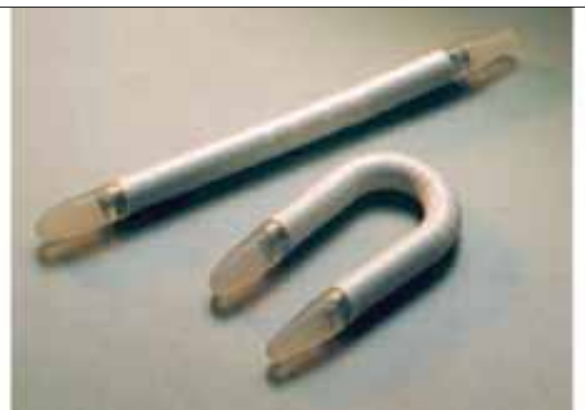

Dura II mechanical penile implant

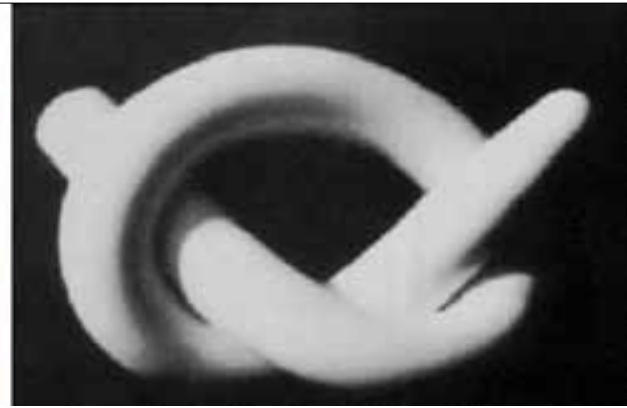

Virilis soft silicone

Figure 2. Noninflatable penile protheses 
Surgical approaches: Surgical approaches for penile prothesis implantation include subcronal (used only for implantation of malleable or postionable devices), infrapubic, and penoscrotal. Infrapubic is the secure placement of the midline location (9). If the prosthesis is placed through an infrapubic incision on the dorsal surface of the corpora cavernosa, care should be taken to avoid damaging the neurovascular bundle. The pump is placed around the side of the penis into the scrotum. During placement of a hydraulic implant, in the penoscrotal or transverse scrotal approach, the resevior is passed blind through the inguinal canal. Care should be taken in this approach to place this part medially to avoid injury to the iliac vessels. The advantages to this approach are the secure placement of the pump in the scrotum and the fact that the skin is not violated in the prepubic area, for more acceptable cosmetic result (Figure 3). The ambicor prosthesis can only be placed through penoscrotal approach. The semi rigid rods and soft silicone implant are commonly placed through a subcoronal, penoscrotal or ventral penile incision.

Penile prosthesis complications: Periprosthetic infection is an important concern for both doctors and patients, not only because it can cause serious illness, but also requires the complete removal of the device. Spontaneous inflation is a potential and bothersome problem with the three-piece inflatable penile prosthesis. Additionally, lack off full glans tumescence, shorter erections, unwanted movement of the pump or reservior, erosion into the urethra, fibrosis, and mechanical failure are other potential complications.

\section{Vascular surgery for erectile dysfunction}

For the young male with erectile dysfunction (ED) or the result of pelvic/perineal trauma, vascular surgery offers an option for potential cure. Penile revascularization is one of the treatments that have the potential to permanently cure patients, that is, allow return of spontaneously developing erections without the necessity for any medications or internal/external device. This procedure has undergone many refinements since its first description (10).

Virag and colleagues described a procedure in which the inferior epigastric artery was anastomosed directly to the deep dorsal vein, introducing concept of venous arterialisations (Virag I-IV) (11).

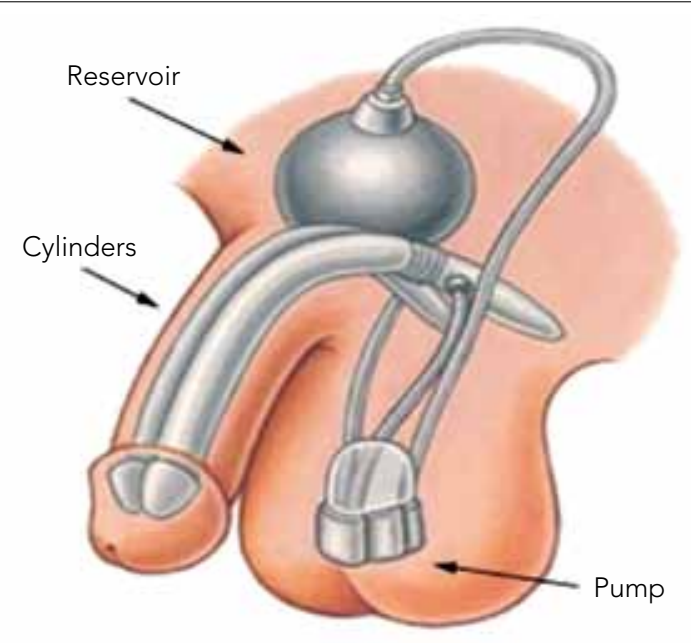

Figure 3. 3-piece Penile Prosthesis surgery technique
The principles of surgery remain the same, consisting of distal or proximal ligation of the arterialized vein, windows between the artery and vein, and ligation of circumflex vessels and destruction of the valves in the dorsal vein. In concept, these procedures may be attractive not only in men with pure arteriogenic ED, but also those with a venogenic component. The specific objective of the surgery is to increase the erectile (cavernosal) artery blood inflow in patients with blood flow related ED secondary to trauma. Young men, without other vascular risk factors (diabetes, high flow pressure, lipid disorders, cigarette smoking), who have ED due to pure arterial blockage, represent the ideal patient population for this procedure.

A list of criteria has been developed that the patient and surgeon must meet to ensure optimum results. The criteria include: 1- Patient must have strong sex drive, 2-Patient must experience a consistent reduction in erectile hardness during sexual activity, 3- Normal hormonal evaluation, 4- Normal neurologic evaluation, 5- Arterial insufficiency on vascular testing, 6- Arterial blockage located in the common penile artery or cavernosal artery, 7- The presence of a donor (inferior epigastric) artery of sufficient length and 8- The surgeon must be trained in microvascular surgery.

The operation is generally performed in a 23-hour fashion (the patient returns home after surgery). Complications are minimal and include abdominal or scrotal pain/swelling and occasional temporary numbness on the top surface of the penis. Abstinence from sexual activity involving the erect penis is recommended for the first 6 weeks after operation. In the hands of a surgeon trained to perform this procedure, this form of surgery is potentially curative for the carefully selected patient with ED. Any young male with ED that may be related to pelvic fracture, trauma to the perineum or prolonged bicycling may be a candidate for this form of surgery.

Cavernous veno-occlusive erectile dysfunction may develop due to congenital factors and trauma in young men, and to acquired factors such as Peyronie's disease, diabetes and late onset hypogonadism in older men. Surgery for penile venous leakage is not recommended in older men because penile venous leakage often results from atrophy of the intracorporeal muscles or the tunica albuginea $(12,13)$. However, when venous leakage is congenital, the deficiency is usually in the large, ectopic, superficial and deep dorsal veins or the large crural veins (12-15). Treatment options for penile venous leakage in men with erectile dysfunction initially included PDE-5 inhibitors as first line treatment and transurethral alprostadil, vacuum construction device or intracavernosal injection as second line treatment $(16,17)$. Surgical treatment may be an option in patients who do not have a response or are not satisfied with less invasive treatments (18). The technical goal of therapy addresses the identified malfunctioning or ectopic deep dorsal, crural, or cavrnosal veins. The surgical procedure has, over time, been expanded from simple deep dorsal vein ligation to extensive surgical exposure and vein ligation, excision, crural plication and spongiolysis performed alone or in combination (12).

Alternatively, venous arterialisations has been applied to decrease venous outflow, particularly when coupled with crural venous ligation or crural ligation and can be used in cases of mixed (arte$\mathrm{rial} /$ venous) vasculogenic erectile dysfunction (19-22). 


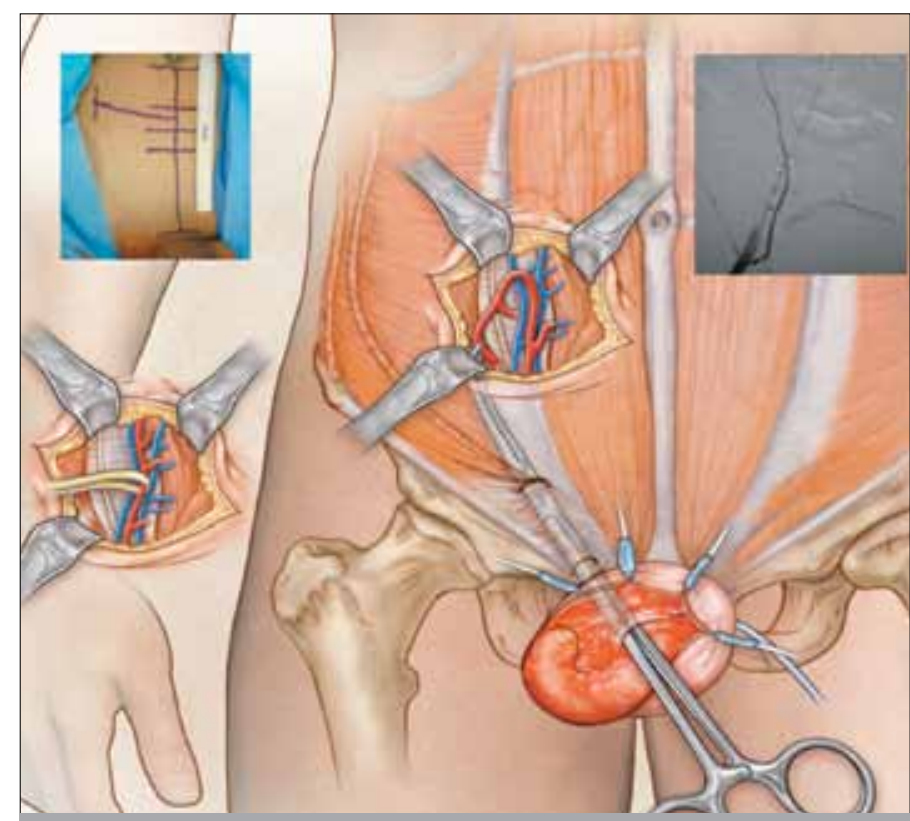

Figure 4. Penile revascularisation surgery technique

Key points in vascular surgery for erectile dysfunction: Vascular surgical procedures are recommended only for a select group of patients. The overall goal of penile revascularisation surgery is the bypass of specific obstructive arterial lesions in the hypogasric-cavernosal arterial bed. This surgery is not indicated in the patient with generalized arterial disease or diabetes mellitus. For penile revascularisation, a common iliac arteriogram and selective internal pudental arteriogram are absolutely necessary. The most common donor artery for penile revascularisation is the inferior epigastric artery, usually connected to the dorsal artery of the penis by microvascular surgery (Figure 4). Also, end to end anastomosis from the arterial donor site to the recipient vessel is the most physiological choice. Penile veno-occlusive surgery, indicated in a select group of patients, should consist of a thorough complete penile vein dissection and ligation. Early results of penile veno-occlusive surgery are much better than long-term results after 2 years. Complications of penile vascular surgery are penile numbness and hypoesthesia and some minor penile shortening (Campell-Walsh urology).

Conflict of interest: No conflict of interest was declared by the authors.

\section{REFERENCES}

1. Scott FB, Bradley WE, Timm GW. Management of erectile impotence: use of implantable inflatable prosthesis. Urology 1973; 2: 80-2. [CrossRef]

2. Virag R. Intracavernous injection of papaverine for erectile failure. Lancet 1982; 2: 938. [CrossRef]

3. Goldstein I, Lue TF, Padma-Nathan H, Rosen RC, Steers WD, Wicker PA Oral sildenafil in the treatment of erectile dysfunction. Sildenafil Study Group. N Engl J Med 1998; 338: 1397-404. [CrossRef]

4. Montague DK. Experience with semirigid rod and inflatable penile prostheses. J Urol 1983; 129: 967-8.

5. Small MP, Carrion HM Gordon JA. Small Carrion Penile Prosthesis: New management of impotance. Urology 1975; 5: 479-86. [CrossRef]

6. Furlow WL. Inflatable penile prosthesis: Mayo clinic experience with 175 patients. Urology 1979; 13: 166-71. [CrossRef]

7. Drogo K. Montague MD. Campbell-Walsh Urology 9th ed. Prosthetic Surgery for Erectile Dysfunction. Philadelphia. pp 789-97.

8. Steidle CP, Mulcahy JJ. Erosion of penile prostheses: a complication of urethral catheterization. J Urol 1989; 142: 736-9.

9. Riemenschneider HW. Epigastric placement of reservior for inflatable penile prosthesis. Urology 1981; 17: 79-81. [CrossRef]

10. Michal V, Kramar R, Pospichal J, Hejhal L. Direct arterial anastomosis on corpora cavernosa penis in the therapy of erective impotence. Rozhl Chir 1973; 52: 587-90.

11. Virag R. Unstable erection due to venous insufficiency. Diagnosis and surgical correction. 10 cases with a mean follow-up 12 months (author's transl). J Mal Vasc 1981; 6: 121-4.

12. Lue TF. Surgery for crural venous leakage. Urology 1999; 54: 739-41. [CrossRef]

13. Montague DK, Barada JH, Bekler AM, et al. Clinical guidelines panel on erectile dysfunction: Summary report on the treatment of organics erectile dysfunction. J Urol 2007; 156: 199.

14. Ebbehøj J, Wagner G. Insufficient penile erection due to abnormal drainage of cavernous bodies. Urology 1979; 13: 507-10. [CrossRef]

15. Stief CG, Gall H, Scherb W, Bähren W. Erectile dysfunction due to ectopic penile vein. Urology 1988; 31: 300-3. [CrossRef]

16. Çayan S. Primary penile venous leakage surgery with crural ligation in men with erectile dysfunction. J Urol 2008; 180: 1056-9. [CrossRef]

17. McMahon CHG. Nonsurgical treatment of cavernosal venous leakage. Urology 1997; 49: 97-100. [CrossRef]

18. Wespes E, Schulman CC. Venous leakage: surgical treatment of a curable cause of impotence. J Urol 1985; 133: 796-8.

19. Löbelenz M, Jünemann KP, Köhrmann KU, Seemann O, Rassweiler J, Tschada $R$, Alken $P$. Penile revascularization in nonresponders to intracavernous injections using a modified microsurgical technique. Eur Urol 1992; 21: 120-5.

20. Sarramon JP, Bertrand N, Malavaud B, Rischmann P, Chamssudin A. Surgical treatments of erectile impotence. Rev Med Interne 1997; 18: 36-40. [CrossRef]

21. Anafarta K, Aydos K, Yaman O. Is deep dorsal vein arterialization an alternative surgical approach to treat venogenic impotence? Urol Int 1997; 59: 109-12. [CrossRef]

22. Breza J, Aboseif SR, Lue TF, Tanagho EA. Cavernous vein arterialization for vasculogenic impotence. An animal model. Urology 1990; 35: 513-8. [CrossRef] 